Indiana Working Papers in South Asian Languages and Cultures

\title{
DEMONSTRATIVES IN THE NOUN PHRASE STRUCTURE OF HAKHA CHIN
}

\author{
July, 2019 \\ James C. Wamsley ${ }^{l}$ \\ ${ }^{1}$ Indiana University Department of Linguistics
}

\begin{abstract}
Demonstratives are versatile grammatical morphemes that perform semantic and pragmatic functions related to spatial deixis, definiteness, familiarity, narratives, discourse, and anaphora. This paper looks at the demonstrative class in Hakha Chin, a Kuki-Chin language in the TibetoBurman family. Hakha Chin demonstratives exhibit several remarkable features, such as their ability to appear in prenominal, postnominal, and circumnominal positions (in which they appear concurrently in prenominal and postnominal positions). This analysis also examines Hakha Chin demonstrative morphosyntax as it relates to other elements in the noun phrase structure, such as case marking, numerals, classifiers, and adjectives. The paper also touches on the relationship between demonstratives and the expression of definiteness and familiarity in Hakha Chin, finding that bare nouns can be interpreted as either definite or indefinite and that there is a dedicated familiarity morpheme kha. The findings of this paper offer several questions for future research on the syntactic structure of Hakha Chin nominal phrases and their semantic interpretations.
\end{abstract}

Key Terms - demonstratives, nominal structure, morphosyntax, Kuki-Chin languages

\section{INTRODUCTION}

Demonstratives are a closed category of lexical items which perform two primary functions in language, the first being a generic deictic (or pointing) function, and the second a grammatical, semantic, and pragmatic function. Demonstratives have been the focus of much research and discussion, in part because of their multitude of utilities and forms in the world's languages (Diessel 1999, Dixon 2003, Dryer 2007). Demonstratives are often linked to $3^{\text {rd }}$ person pronouns, articles, interrogatives, and other grammatical forms. Demonstrative systems of Tibeto-Burman languages have been studied for their syntactic and semantic properties, as well as their historical development. Research on the nominal phrase structure of Tibeto-Burman languages (DeLancey 1980, Chhangte 1993, Baclawski 2012) shows that demonstratives are suitable nominal modifiers for cross-linguistic study.

This paper expands upon research done on the demonstrative systems of Tibeto-Burman languages by looking at the demonstrative system of Hakha Chin, a Kuki-Chin language of the Tibeto-Burman language family spoken by about 165,000 speakers primarily in Burma (VanBik 2009, Simons and Fennig 2018). The form and function of demonstrative elements in the noun phrase structure of Hakha Chin raise several questions for research. Of interest is the fact that Hakha Chin, like some other languages, allows demonstratives to concurrently appear in a prenominal position, where they are minimally distinct with regard to deixis (distance from speaker and addressee) and in postnominal position, which is linked to definiteness, specificity, 
and discourse functions. The pre-nominal and post-nominal syntactic position of demonstratives is shown in example (1).

$\begin{array}{lllll}\text { (1) } & {[\mathbf{h i} \text { mi nu }} & \text { hi }] & \text { a } & \mathrm{kal}^{1} \\ \text { this person woman } & \text { this } & \text { 3PS } & \text { go } \\ \text { "This woman goes." } & & & \end{array}$

The preliminary analysis herein is based in a typological framework established by Dixon (2003), meant to investigate the typological features of demonstratives in the world's languages. This analysis looks at the usage of demonstratives in varying syntactic configurations and corresponding semantic functions in order to highlight potential avenues for future investigation. For the purposes of this paper, I will only address nominal demonstratives, specifically demonstrative words that either appear in a noun phrase or act as a noun phrase themselves.

This paper addresses three questions concerning demonstratives in Hakha Chin. These are: (1) What the demonstratives in Hakha Chin are; (2) how Hakha Chin demonstratives interact with other elements of the noun phrase and; (3) how the syntactic configurations of demonstratives in Hakha Chin contribute to specific semantic and pragmatic interpretations.

As the demonstrative system in Hakha Chin is under-documented, this paper introduces the components of the demonstrative system and remarks on their form, function, and reference following an investigative typology established by Dixon (2003). Then, the paper turns to the morphosyntactic behavior of demonstratives, with a focus on interactions with other elements in the nominal complex such as the head noun, case marking, numerals, classifiers, and adjectives. In investigating the demonstrative system, several relevant questions are raised concerning demonstratives in this language and in general.

The next section provides an overview of previous research related to demonstratives in both Tibeto-Burman and non-Tibeto-Burman languages. Section 3 is a discussion of the morphosyntactic forms of Hakha Chin demonstratives. Sections 4-6 examine the morphosyntactic relationship between demonstratives other elements in the noun phrase: case marking in section 4 , numerals and classifiers in section 5, and adjectives in section 6. Section 7 discusses the role of demonstratives in definiteness marking. Section 8 concludes the paper.

\section{BACKGROUND}

Dixon and Diessel define four types of demonstratives based on the function they perform and their syntactic behavior. Previous work on demonstratives has focused not only on describing demonstrative systems in specific languages but also on establishing typologies of demonstrative systems. In an overview of theory and research involving the study of demonstratives, Dixon (2003) defines demonstratives as a closed category of grammatical words which can have a pointing (or deictic) reference. Dixon divides them into three main types (nominal, local adverbial, and verbal) based on their demonstrative function. Diessel (1999) proposes different categories (demonstrative pronouns, demonstrative determiners, demonstrative adverbs, and demonstrative identifiers) in his description of the origin, function, and typology of demonstratives in the world's languages. An overview of Dixon and Diessel is presented in Table 1.

\footnotetext{
${ }^{1}$ This paper uses Hakha Chin orthography.
} 
Indiana Working Papers in South Asian Languages and Cultures

Table 1. Demonstrative Categories in Dixon 2003 and Diessel 1999²

\begin{tabular}{|l|l|l|l|}
\hline Example & $\begin{array}{l}\text { Demonstrative } \\
\text { Function }\end{array}$ & Dixon 2003 & Diessel 1999 \\
\hline $\begin{array}{l}\text { This woman is } \\
\text { my wife }\end{array}$ & $\begin{array}{l}\text { appearing with a noun } \\
\text { or pronoun }\end{array}$ & nominal demonstrative & $\begin{array}{l}\text { demonstrative } \\
\text { determiner }\end{array}$ \\
\hline That is my wife & acting as a noun phrase & nominal demonstrative & demonstrative pronoun \\
\hline My wife is here & $\begin{array}{l}\text { modifying a verb, often } \\
\text { indicating a location }\end{array}$ & $\begin{array}{l}\text { local adverbial } \\
\text { demonstrative }\end{array}$ & demonstrative adverb \\
\hline
\end{tabular}

Scholars have also studied properties of discourse usage related to demonstratives. Gärdenfors and Brala-Vukanović (2018) use data from Croatian to explore deictic referentiality, positing that demonstratives and articles are part of a class of "fast semantics" whose meanings can be derived from a combination of spatial and discourse reference, as opposed to the category of "slow" semantics, in which meaning is determined within a speech community over a period of time.

Research on demonstrative systems in Tibeto-Burman languages has focused on the deictics of Tibeto-Burman verbs (DeLancey 1980) and has outlined the historical morphophonemics of demonstratives in Tibeto-Burman (Benedict 1983). Syntactic studies of Tibeto-Burman demonstratives systems include Liu and Gu (2009), who examined the syntactic distribution of Jingpo demonstratives, and Chhangte (1993), which describes the syntactic qualities of the demonstrative system in Mizo, another member of the Kuki-Chin language family. Baclawski (2012) outlines the deictic system of Hyow, another Kuki-Chin language, where he posits that demonstratives in Kuki-Chin languages expanded from the spatial domain and were grammaticalized into discourse markers. He claims that deictics in Kuki-Chin can mark topic, focus, and tense (Baclawski 2012).

Past work on Tibeto-Burman demonstratives has also looked at Hakha Chin, including investigations of the morphological structure and usage of demonstratives in deictic and discourse contexts (Barnes 1998), as well as an analysis of their interactions with the semantics of focus and contrast (Hlun 2007). Despite this work, however, many questions remain due to the complexity of these interactions. As Peterson (2002) puts it, "The morphology of these discourse particles is virtually identical to that of prenominal demonstratives, but their semantic effect is quite complex."

Dryer (2007), in an overview of nominal phrase structures across languages, highlights and explains different arrangements of functional elements which coexist alongside nominals. He discusses the demonstrative systems of languages such as Milang (Tayeng 1976) and Nishi (Hamilton 1900), which resemble Hakha Chin in that demonstratives occur in both prenominal and postnominal positions simultaneously, as in (2-3), a pattern is also found in Malagasy (Keenan and Polinsky 2001).

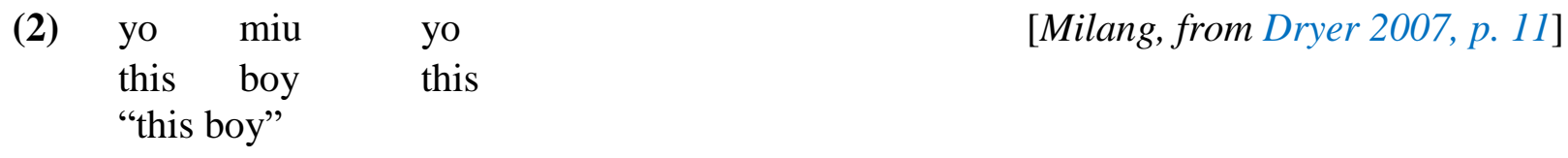

\footnotetext{
${ }^{2}$ In addition to these categories, Dixon (2003) and Diessel (1999) identify a $4^{\text {th }}$ category of verbal demonstratives that function alone as verbs referring to the manner in which an action is done. This phenomenon has not been attested in Hakha Chin and is not discussed in this paper.
} 
(3)

$$
\begin{aligned}
& \text { sa mindui si } \\
& \text { this buffalo this } \\
& \text { "this buffalo" }
\end{aligned}
$$

[Nishi, from Dryer 2007, p. 11]

Data on Hakha Chin demonstratives were gathered by meeting regularly with a native speaker consultant fluent in the Thantlang variety of Hakha Chin. The consultant is a male university student who is also fluent in English. The consultant was presented with example English sentences and contexts seeking to elicit noun phrases with minimal distinctions in distance, definiteness, specificity, discourse relevance, etc. The demonstrative-focused questionnaire (Wilkins 1999) was also employed in order to obtain data on the spatial reference of demonstratives in Hakha Chin. English sentences and contexts were otherwise constructed by the author based on Dixon (2003).

The next section introduces the two main categories of demonstratives in Hakha Chin with comments on their morphosyntatctic behavior. After establishing the forms of Hakha Chin demonstratives, sections 4-6 discuss their behavior when combined with other elements in the noun phrase.

\section{HAKHA CHIN DEMONSTRATIVES}

Hakha Chin has two categories of demonstratives: deictic and non-deictic demonstratives. Following Dixon's typological conditions for performing a deictic function, deictic demonstratives make reference to the spatial position of the referent head noun relative to the speaker and are discussed further in section 3.1. Non-deictic demonstratives do not perform a deictic function within the noun phrase and are discussed further in section 3.2.

\subsection{Deictic Demonstratives}

The deictic demonstratives in Hakha Chin are outlined in Table 2 below.

Table 2. Hakha Chin Deictic Demonstratives

\begin{tabular}{|l|l|l|}
\hline$h i$ & near speaker & "this" \\
\hline$k h a$ & near addressee & "that" \\
\hline$k h i$ & far from speaker and addressee & "that (over there)" \\
\hline
\end{tabular}

Hakha Chin deictic demonstratives are adnominals, meaning that they co-occur with a referent head noun as opposed to appearing as morphological inflection. The syntactic configuration of deictic demonstratives is varied in that they are able to occur in prenominal position before the noun, postnominal position after the noun, and in a circumnominal configuration, where demonstratives appear both before and after the referent head noun. Post-nominal position is generally the canonical site for demonstratives in Hakha Chin, with other configurations occurring in more limited situations. All three of the deictic demonstratives appear postnominally while performing their deictic pointing function, as in (4-6). 
$\begin{array}{llll}\text { (4) uico } & \text { hi } & \text { a } & \text { lian } \\ \text { dog } & \text { this } & 3 \mathrm{SG} & \text { big }\end{array}$

"This dog is big."

(5) uico kha a lian

dog that 3SG big

"That dog is big."

(6) uico khi a lian

dog that 3SG big

"That dog (over there) is big."

The deictic demonstratives can also appear in prenominal position, but only when accompanied with postnominal $c u$ which functions in examples (7-9) as a topicalizer (Barnes 1998, Bedell 2001).

(7) hi uico $*(\mathrm{cu})$ a lian

this dog TOP 3SG big

"This dog is big."

(8) kha uico $*(\mathrm{cu})$ a lian

that $\operatorname{dog}$ TOP $3 \mathrm{SG}$ big

"That dog is big."

(9) khi uico *(cu) a lian

that $\operatorname{dog}$ TOP 3SG big

"That dog (over there) is big."

In addition to appearing in the canonical postnominal position, and co-occuring prenominally with postnominal topicalizer $c u$, deictic demonstratives can also appear circumnominally (simultaneously in both prenominal and postnominal positions). In such constructions, both deictic markers must match one another in form, as shown in examples (10-12). Although examples (79) and (10-12) have the same English translations as (4-6), the deictic demonstratives appear in different syntactic configurations.

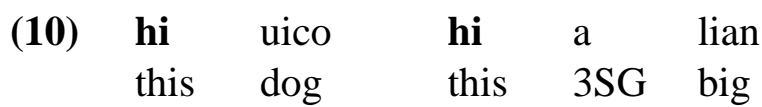

"This dog is big."

$\begin{array}{lllll}\text { (11) kha } & \text { uico } & \text { kha a } & \text { lian } \\ \text { that } & \text { dog } & \text { that } & 3 S G & \text { big }\end{array}$

"That dog is big."

$\begin{array}{lllll}\text { (12) khi } & \text { uico } & \text { khi } & \text { a } & \text { lian } \\ \text { that } & \operatorname{dog} & \text { that } & 3 S G & \text { big }\end{array}$

"That dog (over there) is big." 


\subsection{Non-deictic Demonstratives}

In addition to the category of deictic demonstratives which are minimally distinct with regard to spatial distance, there is another category of non-deictic elements which belong to the demonstrative paradigm. This category includes a generic demonstrative mah which does not in itself contain semantic information about spatial relations between speaker and referent, and a remote demonstrative $c u^{3}$ for non-visible referents. The generic demonstrative mah is more restricted in the number of possible syntactic configurations. First, like the deictic demonstratives, it can only appear prenominally when the postnominal topicalizer is present. Second, it can only appear in prenominal position and can never appear in postnominal position, either alone or with other demonstrative elements. Examples (13-15) contain the generic mah appearing prenominally in conjunction with a postnominal deictic demonstrative.

(13) mah uico hi a lian

DEM dog this 3SG big

"This dog is big."

(14) mah uico kha a lian

DEM dog that 3SG big

"That dog is big."

(15) mah uico khi a lian

DEM dog that 3SG big

"That dog (over there) is big."

The generic demonstrative mah must appear in prenominal position with a postnominal demonstrative, as seen in example (16).

$\begin{array}{llll}* \text { mah } & \text { uico } & \text { a } & \text { lian } \\ \text { DEM } & \text { dog } & 3 S G & \text { big }\end{array}$

The non-visible demonstrative $c u$ functions similarly to the deictic demonstratives in that it can appear postnominally with mah and prenominally with the topicalizer $c u$, as seen in example (17-18). In example (17), the postnominal $c u$ is not a topicalizer because as is shown in (16), mah cannot appear without another demonstrative appearing postnominally. The topicalizer $c u$ is unable to imbue the generic mah with deictic reference and therefore, the postnominal $\mathrm{cu}$ in (17) must be the remote demonstrative.

$\begin{array}{lllll}\text { mah uico } & \text { cu } & \text { a } & \text { lian } \\ \text { DEM dog } & \text { REM } & \text { 3SG } & \text { big } \\ \text { "That dog was big." } & & & \end{array}$

\footnotetext{
${ }^{3}$ The non-visible demonstrative $c u$ resembles the topicalizer $c u$ seen in examples (7-9). I posit here that the topicalizer is historically derived from the non-visible demonstrative. The topicalizer $c u$ is not the focus of this paper and will be addressed in future research.
} 
(18)

$\begin{array}{lllll}c u & \text { uico } & \text { cu } & \text { a } & \text { lian } \\ \text { REM dog } & \text { TOP } & \text { 3SG } & \text { big } \\ \text { "The dog is big." } & & & \end{array}$

Like the deictic demonstratives, the prenominal remote demonstrative $c u$ cannot be used without a postnominal topicalizer as shown in example (19).

$\begin{array}{llll}* \text { cu } & \text { uico } & \text { a } & \text { lian } \\ \text { REM } & \text { dog } & \text { 3SG } & \text { big }\end{array}$

This section has established the members of the Hakha Chin adnominal demonstrative class and provided examples of their various morphosyntactic configurations. Sections (4-6) look at the deictic demonstratives in the Hakha Chin nominal phrase structure and their interactions with nouns (with various case marking) in section 4 , numbers and classifiers in section 5 , and adjectives in section 6 following a demonstrative typological framework developed by Dixon (2003). This is followed by notes on definiteness marking in Hakha Chin in section 7 .

\section{HAKHA CHIN DEMONSTRATIVES AND CASE MARKING}

Case marking provides the conditioning environment for demonstrative allomorphy in Hakha Chin. Hakha Chin has a split ergative system (Peterson 2002), in which full nouns (as opposed to pronouns) in absolutive case are unmarked and nouns in ergative case are marked postnominally with the clitic nih as shown in example (20).

$\begin{array}{llll}\text { uico=nih } & \text { chizawh } & \text { a } & \text { dawi } \\ \operatorname{dog}=\text { ERG } & \text { cat } & \text { 3SG } & \text { chase }\end{array}$

"The dog chased a cat."

Additionally, Hakha Chin has enclitics to mark nouns in locative (21) and instrumental case (22).

$$
\begin{array}{lllll}
\text { fawn } & \text { cu } & \text { cabuai=ah } & \text { a } & \text { um } \\
\text { phone } & \text { TOP } & \text { table=LOC } & \text { 3SG } & \text { be.at }
\end{array}
$$

"The phone is on the table."

$$
\begin{aligned}
& \text { arti=he ka chumh } \\
& \text { egg=INS 1SG cook } \\
& \text { "I cook with eggs." }
\end{aligned}
$$

When nouns are marked for case (ergative, locative, or instrumental), the postnominal demonstrative exhibits allomorphy, with $-n$ appended to the demonstrative. When nouns are in absolutive case, that is, when they are the subjects of intransitive verbs or objects of transitive verbs, they exhibit no case marking. When nouns are the subjects of transitive verbs, they are in ergative case and are thus marked postnominally with the case marker nih. Examples are included below for absolutive case with no allomorphic alteration in (23), ergative case with $-n$ marked added to the demonstrative in (24), locative with $-n$ added to the demonstrative in (25), and 
instrumental with - $n$ added to the demonstrative in (26). The brackets in these examples mark the boundaries of relevant noun phrases.

$\begin{array}{llll}\text { [hi minu }=\emptyset^{4} & \text { hi] } & \text { a } & \text { kal } \\ \text { this woman.ABS } & \text { this } & 3 \mathrm{SG} & \text { go } \\ \text { "This woman left." } & & & \end{array}$

(24) [hi minu=nih hin] ca a ttial thiswoman=ERG this paper 3SG write "This woman writes a paper."

$\begin{array}{llllllll}\text { na } & \text { fawn } & \mathrm{cu} & {[\mathrm{hi}} & \text { cabuai=ah } & \text { hin }] & \text { a } & \text { um } \\ \text { 2SG.GEN phone } & \text { TOP } & \text { this } & \text { table=LOC } & \text { this }] & \text { 3SG } & \text { be.at }\end{array}$
"Your phone is on this table."

(26) $[$ hi arti=he hin $]$ ka chumh this egg=INS this $1 \mathrm{SG}$ cook "I cook with this egg."

The same morphological alterations can be observed for postnominal $k h a$ and $k h i$ in examples (27-34) where like $h i$, the demonstrative appears in prenominal and postnominal position and the postnominal demonstrative exhibits the allomorphic form with - $n$ when the noun is case marked.

[kha minu $=\varnothing \quad$ kha] a kal

that woman.ABS that 3SG go

"That woman left."

(28) $\quad[$ kha minu=nih khan $]$ ca a ttial that woman=ERG that paper $3 \mathrm{SG}$ write "That woman writes a paper."

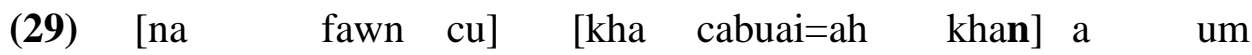
2SG.Gen phone TOP that table=LOC that 3SG be.at "Your phone is on that table."

(30) $\quad[$ kha arti=he khan $]$ ka chumh this egg=INS this $1 \mathrm{SG}$ cook "I cook with that egg."

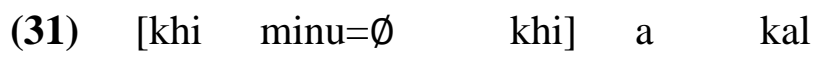
that woman.ABS that 3SG go "That woman (over there) has left."

\footnotetext{
${ }^{4}$ Absolutive case is marked in this section to show contrast with ergative, locative and instrumental case marking.
} 
(32)

[khi minu=nih khin] ca a ttial

that woman=ERG that paper $3 \mathrm{SG}$ write

"That woman (over there) writes a paper."

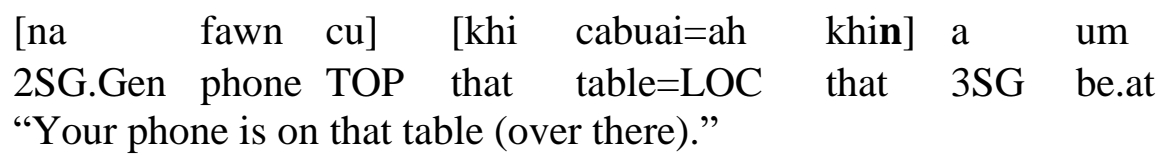

(34) [khi arti=he khin] ka chumh

that egg=INS that $1 \mathrm{SG}$ cook

"I cook with that egg (over there)."

In each of these example sentences, the postnominal demonstrative follows the case marking enclitic, whether it is ergative, locative, or instrumental. This has implications for the syntactic hierarchical structure of the Hakha Chin noun phrase, though this will not be addressed in this paper. As for the allomorphic form of the postnominal demonstrative, Barnes (1998) and Chit Hlaing and Hlun (2003) argue that the historical origin of the $-n$ suffix is the contraction of the in oblique case marker. As of yet, no syntactic account has been proposed for the interaction of case marking and postnominal demonstratives.

This section has highlighted one of the unique characteristics of Hakha Chin demonstratives: allomorphic alteration triggered by the presence of case marking on the head noun. The next section will look at the morphosyntactic configuration of demonstratives with numbers and classifiers.

\section{HAKHA CHIN DEMONSTRATIVES AND NUMBERS AND CLASSIFIERS}

This section looks at the interactions between demonstratives, numbers, and classifiers. According to Dixon (2003), if a language has classifiers which are used in multiple contexts, occurrence with demonstratives is often one of them. There may be a different set of classifiers used with demonstratives or they may have a different form, ordering, or different degree of obligatoriness. There can be a dependency between the spatial/visibility system and the number system. Hakha Chin has a classifier system, meaning that in noun phrases with number morphology, there is a classifier accompanying the numeral and noun. In Hakha Chin, nouns, numerals, and classifiers always appear in a sequence of [Noun+Classifier+Numeral]. Examples (35-37) below illustrate the morphosyntax of numbers and classifiers in the Hakha Chin nominal structure with an animate head noun (35), and two inanimate nouns (36-37) each appearing in the sequence of $[\mathrm{N}+\mathrm{CL}+\mathrm{Num}]$.

$\begin{array}{lll}{[\mathrm{N}} & \mathrm{CL} & \text { Num }] \\ \text { minung } & \text { pa } & \text { khat } \\ \text { person } & \mathrm{CL} & \text { one } \\ \text { "one person" } & \end{array}$


(36)

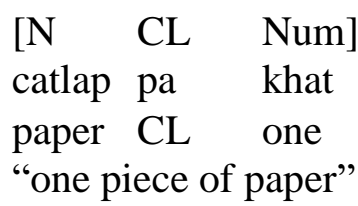

$\left[\begin{array}{lll}\mathrm{N} & \mathrm{CL} & \mathrm{Num}\end{array}\right]$

(37) arti pa khat

egg CL one

"one egg"

The default classifier $p a$ is used for most nouns while other classifiers are rarely employed. This is reflected in the citation for numbers in Hakha Chin, shown in (38-40).

(38) pakhat

"one"

(39) pahnih

"two"

(40) pathum

"three"

It appears that the generic classifier $p a$ has been integrated into the lexical form of the number. However, there are some instances in which lexically-defined classifiers are still used. Examples of lexically-specified classifiers for the nouns paper in (41) and egg (42) are shown below.

(41) catlap tlap khat a um paper CL one 3SG be.at "There is one piece of paper."

(42) arti pum khat a um egg CL one 3SG be.at "There is one egg."

In these examples, the numeral root is khat, as opposed to the citation form shown in (38) above. In Hakha Chin, there is an option to use the generic classifier $p a$ or the lexically-designated classifier, though the implications for either choice are unclear.

In nominal structures with numerals, demonstratives appear in circumnominal syntactic configurations. While prenominal demonstratives still appear immediately preceding the head referent noun, postnominal demonstratives always appear following the classifier-numeral sequence in the order $[\mathrm{Dem}+\mathrm{N}+\mathrm{CL}+\mathrm{Num}+\mathrm{Dem}]$ as in (43-45).

$\begin{array}{lllll}\text { Dem } & \mathrm{N} & \mathrm{CL} & \text { Num } & \text { Dem } \\ {[\mathrm{hi} \text { minung }} & \text { pa } & \text { khat } & \text { hi }] \\ \text { this person } & \mathrm{CL} & \text { one } & \text { this } \\ \text { "this one person" } & & & \end{array}$




\begin{tabular}{|c|c|c|c|c|c|}
\hline (44) & $\begin{array}{l}\text { Dem } \mathrm{N} \\
\text { [hi catlap } \\
\text { this paper } \\
\text { "I write this on }\end{array}$ & $\begin{array}{l}\text { CL } \\
\text { pa } \\
\text { CL } \\
\text { aper.' }\end{array}$ & $\begin{array}{l}\text { Num } \\
\text { khat } \\
\text { one }\end{array}$ & $\begin{array}{l}\text { Dem } \\
\text { hi] } \\
\text { this }\end{array}$ & $\begin{array}{l}\mathrm{ka} \\
1 \mathrm{SG}\end{array}$ \\
\hline (45) & $\begin{array}{ll}\text { Dem } & \mathrm{N} \\
\text { [hi } & \text { arti } \\
\text { this } & \text { egg }\end{array}$ & $\begin{array}{l}\text { CL } \\
\text { pum } \\
\text { CL }\end{array}$ & $\begin{array}{l}\text { Num } \\
\text { khat } \\
\text { one }\end{array}$ & $\begin{array}{l}\text { Dem } \\
\text { hi] } \\
\text { this }\end{array}$ & $\begin{array}{l}\mathrm{ka} \\
1 \mathrm{SG}\end{array}$ \\
\hline
\end{tabular}

When there is case marking on the noun, it also follows the classifier-numeral sequence and is followed by the demonstrative, as in (46).

\begin{tabular}{|c|c|c|c|c|c|c|c|}
\hline $\begin{array}{l}\text { Dem } \\
\text { [hi } \\
\text { this }\end{array}$ & $\begin{array}{l}\mathrm{N} \\
\text { arti } \\
\text { egg }\end{array}$ & $\begin{array}{l}\text { CL } \\
\text { pa } \\
\text { CL }\end{array}$ & $\begin{array}{l}\text { Num } \\
\text { khat } \\
\text { one }\end{array}$ & $\begin{array}{l}\text { Case } \\
\text { he } \\
\text { INST }\end{array}$ & $\begin{array}{l}\text { Dem } \\
\text { hin] } \\
\text { this }\end{array}$ & $\begin{array}{l}\mathrm{ka} \\
1 \mathrm{SG}\end{array}$ & $\begin{array}{l}\text { chumh } \\
\text { cook }\end{array}$ \\
\hline
\end{tabular}

In addition to cardinal number words such as those shown in the examples above, Hakha Chin also has a plural word hna, which marks a nominal as plural. Plural words differ from plural affixes in that they mark the noun as plural but do not appear as part of the head noun's morphological structure (Dryer 2007). Instead, they appear as separate words, sometimes elsewhere in the sentence. Similar behavior with a plural word has been observed in Bawm, a Tibeto-Burman language in Bangladesh (Reichle 1981, via Dryer 2007). The plural word hna in Hakha Chin appears most frequently postverbally to mark the object of a transitive as plural. Examples (47-48) below show the contrast with the usage of the plural word hna. Example (47) contains a singular object and hna is not present. In example (48), there is a plural object, here marked with hna, following the verb.

(47)

$\begin{array}{lll}\text { uico chizawh a } & \text { dawi } \\ \text { dog cat } & \text { 3SG chase } \\ \text { "A dog chased a cat." }\end{array}$

(48)

$\begin{array}{lllll}\text { uico chizawh a } & \text { dawi } & \text { hna } \\ \text { dog cat } & \text { 3SG } & \text { chase } & \text { PL } \\ \text { "A dog chased cats." }\end{array}$

The plural word can also mark subjects as plural. When marking the subject, the plural word appears after the head noun and before the postnominal demonstrative, as in (49).

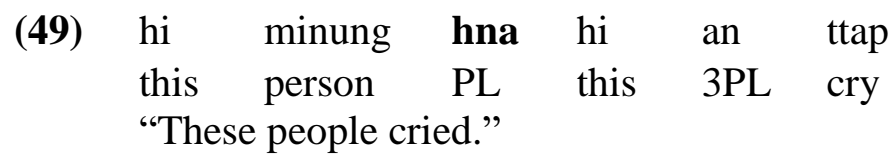


When there is both case marking and a plural word, the sequence is [Dem $+\mathrm{N}+\mathrm{Pl}+\mathrm{Case}+\mathrm{Dem}]$, seen in example (50).

(50)

$\begin{array}{lllllll}\text { khi hngakchia } & \text { hna } & \text { nih } & \text { khin chizawh an dawi } \\ \text { that child } & \text { PL } & \text { ERG } & \text { that cat } & \text { 3PL chase }\end{array}$

"Those children (over there) chased a cat."

The examples above show that when there is number marking or plural marking in Hakha Chin, these elements follow the head noun and always precede the postnominal demonstrative. The next section looks at the interactions between demonstratives and adjectives.

\section{HAKHA CHIN DEMONSTRATIVES AND ADJECTIVES}

Additional elements that interact with demonstratives in the noun phrase are adjectives. There is a paucity of research on adjectives in Hakha Chin. However, Bedell and Lalremzami (unpublished) provides an analysis of Hakha Chin adjectives, concluding that Hakha Chin contains adjectival verbs as well as adjectives which directly qualify a noun when placed prenominally or postnominally. Examples (51-52) from Bedell and Lalremzami (unpublished) below are adapted from Hay-Neave (1953). In (51), mi functions as a relativizer and thus (51) would more accurately be translated as "this is a house that is good". Example (52) contains the noun phrase "good house" with thra functioning as a postnominal adjective.

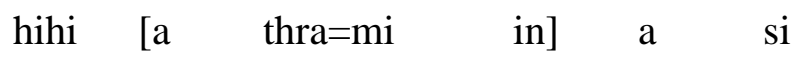

this $3 \mathrm{SG}$ good=REL house $3 \mathrm{SG}$ be

"This is a house which is good." [Bedell and Lalremzami unpublished, p.1]

(52) hihi [in thra] a si

this house good $3 \mathrm{SG}$ be

"This is a good house." [Bedell and Lalremzami unpublished, p.1]

Example (52) shows that qualitative adjectives such as "good" appear postnominally in Hakha Chin. Further data gathered from a language assistant show that qualitative adjectives such as lian 'big' are followed by a modificational particle pi, as seen in (53). Meanwhile, referential adjectives such as 'American' are prenominal, as shown in example (54). Example (55) shows the combination of a prenominal referential adjective and a postnominal qualitative adjective. Example (56) contains the relativizer $m i$, as seen in example (51) above.

$\begin{array}{lll}\text { uico } & \text { lian } & \text { pi } \\ \text { dog } & \text { big } & \text { MOD } \\ \text { "big dog" } & & \end{array}$

(54) American uico

American dog

"American dog" 
(55)

American uico lian pi

American dog big MOD

"big American dog"

(56) a lian=mi uico

3SG big=REL dog

"a dog that is big"

Postnominally, a sequence of two qualitative adjectives is disallowed and must be formed paraphrastically with stative verbs. Example (53) shows that individually, lian is a viable adjective which can appear postnominally. However, in example (57), a sequence of two adjectives is disallowed.

$$
\begin{array}{lll}
* \text { uico } & \text { lian } & \text { rang } \\
\text { dog } & \text { big } & \text { white }
\end{array}
$$

Examples (58) and (59) show that instead of describing a referent noun with a sequence of two adjectives, both adjectives can be integrated into the nominal and verbal complex paraphrastically.

$\begin{array}{lllll}\text { uico lian cu a } & \text { rang } \\ \text { dog big } & \text { TOP } & \text { 3SG } & \text { white } \\ \text { "The big dog is } & \text { white." }\end{array}$

$\begin{array}{lllllll}\text { uico } & \text { cu } & \text { a } & \text { lian } & \text { i } & \text { a } & \text { rang } \\ \text { dog } & \text { TOP } & \text { 3SG } & \text { big } & \text { CONJ } & \text { 3SG } & \text { white } \\ \text { "The dog is big and white." } & & & \end{array}$

Postnominal demonstratives follow the adjective and modificational particle, as in (60).

$(60)$

$\begin{array}{llllll}\text { [hi uico lian } & \text { pi hi] } & \text { chizawh } & \text { a } & \text { dawi } \\ \text { thisdog } & \text { big } & \text { MOD this } & \text { cat } & \text { 3SG } & \text { chase } \\ \text { "This big dog chased a cat." } & & & & \end{array}$

"This big dog chased a cat."

This examination of adjectives in Hakha Chin shows that they, like demonstratives, appear in both prenominal and postnominal positions. Whether the adjective appears prenominally or postnominally, the postnominal demonstrative always follows the postnominal adjective.

In looking at the interactions of demonstratives with case marking, numbers, classifiers, and adjectives it has been shown more generally that the postnominal demonstrative always appears at the rightmost periphery of the nominal complex. Thus, we have the following structure for the nominal complex in Hakha Chin:

\section{[DEM [head N] classifier numeral adjective case DEM]}

Section (7) provides a preliminary analysis of the definiteness interpretations related to the various syntactic configurations of demonstratives in nominal phrases in Hakha Chin. 


\section{HAKHA CHIN DEMONSTRATIVES AND DEFINITENESS MARKING}

Demonstratives often perform a definiteness marking function (Dryer 2007). With demonstratives appearing in multiple positions within the Hakha Chin noun phrase and the lack of a definite article, it is possible that Hakha Chin utilizes demonstratives to express definiteness on the head noun. This section examines definiteness marking in Hakha Chin and the relation of demonstratives to definiteness marking.

In Hakha Chin, preverbal bare nouns without demonstrative, quantificational, or adjectival marking can represent both definite and indefinite referents, as in (61).

$\begin{array}{lll}\text { uico=nih chizawh a dawi } \\ \text { dog=ERG cat } & \text { 3SG } & \text { chase } \\ \text { "A/the dog chased a/the cat." } & \end{array}$

Conversely, preverbal and postverbal nouns which have circumnominal demonstrative marking are definite. Demonstratives typically imbue referent nouns with definiteness (Abbott 2004). In (62), both subject and object contain circumnominal demonstratives and are definite.

$\begin{array}{lllllll}\text { [cu uico=nih } & \text { cun }] & {\left[\begin{array}{lll}\text { cu chizawh } & \text { cu }\end{array}\right]} & \text { a } & \text { dawi } \\ \text { DEM dog=ERG TOP } & \text { DEM } & \text { cat } & \text { TOP } & 3 S G & \text { chase } \\ \text { "The dog chased the cat." } & & & & & \end{array}$

A related concept to definiteness is familiarity, meaning that the referent is in the common ground of discourse for speaker and listener. Familiarity is sometimes marked with a different morpheme, as in Akan (Arkoh and Matthewson 2013). Familiarity in Hakha Chin is marked postnominally with $k h a$ (Barnes 1998), shown in example (63).

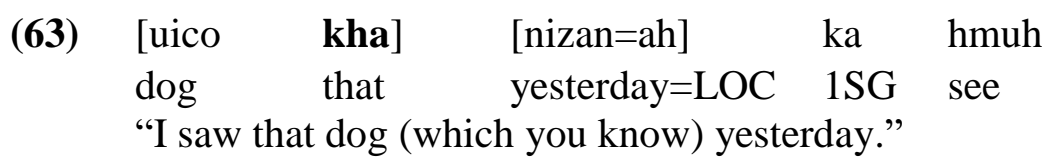

[Barnes 1998, p. 60]

Usage of kha as a marker of familiarity contrasts phonetically with the postnominal medial demonstrative. The medial demonstrative is pronounced as $\left[\mathrm{k}^{\mathrm{h}}\right.$ ə], while the familiarity form is pronounced [ $\left.\mathrm{k}^{\mathrm{h}} \mathrm{a}\right]$ ]. Hakha Chin examples below show different semantic interpretations for nouns with numerals and demonstratives in varying syntactic configurations. In (64), there are no demonstratives on the noun and the referents were reported by the language assistant to be taken as indefinite. In example (65), there is a postnominal demonstrative present and the noun phrase is interpreted as specific. Example (66) makes both specific and spatial refence when there is a circumnominal configuration ${ }^{5}$.

\footnotetext{
${ }^{5}$ It is at this point uncertain how the interaction of number morphology and demonstrative marking in the nominal complex affects the semantic interpretations of definiteness for the referent noun.
} 
(64) [uico pa thum nih] chizawh an dawi

dog CL three ERG cat 3PP chase

"Three dogs chased a cat."

(65) [uico pa thum nih hin] chizawh an dawi

dog CL three ERG this cat 3PP chase

"Three of these dogs chased a cat."

(66) [hi uico pa thum nih hin] chizawh an dawi

this dog CL three ERG this cat 3PP chase

"These three dogs chased a cat."

This section has shown several of the ways in which demonstratives interact with the semantic interpretation of nominals. First, it has shown that Hakha Chin allows for both definite and indefinite interpretations for bare nouns, and when nouns contain circumnominal demonstratives, they are interpreted as definite. Second, Hakha Chin has been shown to have a dedicated morpheme kha which marks familiarity, a concept related to definiteness. Finally, the different syntactic configurations of demonstratives in Hakha Chin yield different semantic interpretations.

\section{CONCLUSION}

This paper has outlined several features of demonstratives in Hakha Chin. Hakha Chin demonstratives can be categorized as having a deictic function, in which there is spatial reference, and non-deictic functions. Syntactically, Hakha Chin demonstratives can appear in prenominal and postnominal positions. They can also appear concurrently in prenominal and postnominal position in a circumnominal configuration. When co-occurring with case marking, numerals, classifiers, and adjectives, postnominal demonstratives appear in final position. Finally, although definiteness marking is ambiguous for bare nouns, there is a dedicated morpheme for familiarity marking on the noun. The data presented here also show that the multiple syntactic configurations of demonstratives (prenominal, postnominal, and circumnominal) lead to differing semantic interpretations of the head noun with regard to definiteness and other deictic properties.

The formal and morphosyntactic behavior of demonstratives in Hakha Chin presents many semantic and syntactic questions regarding their function and interpretations. Semantic questions include how different demonstrative configurations interact with interpretations of definiteness and familiarity of the head noun, whether there is a dedicated process for marking definiteness via demonstratives, and how other aspects of definiteness including uniqueness and identifiability are represented. Syntactic questions revolve around the underlying syntactic structure of the Hakha Chin noun phrase, the process by which case marking on the head noun conditions allomorphy on postnominal demonstratives, and movement operations occurring when demonstratives appear prenominally with a postnominal topicalizer. Future research will investigate these properties of Hakha Chin demonstratives. 


\section{REFERENCES}

Abbott, B. (2004) "Definiteness and indefiniteness," in The Handbook of Pragmatics, edited by L. Horn and G. Ward (Blackwell Publishing, Ltd., Malden, Massachusetts), pp. 122-149. Arkoh, R. and Matthewson, L. (2013) “A Familiar Definite Article in Akan,” Lingua 123 (2013), $1-30$.

Baclawski, K. (2012) "Deictic Elements in Hyow and Kuki-Chin,” Master's thesis, Dartmouth University, Hanover, New Hampshire, pp. 1-131.

Barnes, J. (1998) "Tsuu khaa tii hla?: Deixis, Demonstratives and Discourse Particles in Lai Chin," Linguistics of the Tibeto-Burman Area 21 (1), 53-86.

Bedell, G. (2001) "The Syntax of Deixis in Lai," Linguistics of the Tibeto-Burman Area 24 (2), 157-71.

Bedell, G and Lalremzami, C. (2001) "Adjectives in Lai," unpublished.

Benedict, P. (1983) "This and That in TB/ST," Linguistics of the Tibeto-Burman Area. 7 (2). 75 98.

Chhangte, L. (1993) “Mizo Syntax,” PhD. dissertation, University of Oregon, Eugene, Oregon, pp. 1-223.

Chit Hlaing, F.K.L. \& Hlun, C. (2003) "The Proper Syntax of Case and the Determiner Phrase (DP) in Lai Chin," Linguistics of the Tibeto-Burman Area 26 (1), 23-32.

DeLancey, S. (1980) "Deictic categories in the Tibeto-Burman Verb," PhD. dissertation, Indiana University, Bloomington, Indiana, pp. 1-284.

Diessel, H. (1999) "The morphosyntax of demonstratives in synchrony and diachrony," Linguistic Typology 3 (1999), 1-49.

Dixon, R. (2003) "Demonstratives: A Cross-Linguistic typology," Studies in Language 27 (1), 61-112.

Dryer, M. (2007) "Noun phrase structure," in Language Typology and Syntactic Description: Complex Constructions, Second Edition - Volume II, edited by T. Shopen (Cambridge University Press, Cambridge, England), pp. 151-205.

Gärdenfors, P. and Brala-Vukanović, M. (2018) "Semantic Domains of Demonstratives and Articles: A View of Deictic Referentiality Explored on the Paradigm of Croatian Demonstratives" Lingua 201 (2018), 102-118.

Hamilton, R. C. (1900) An Outline Grammar of the Dafla Language (The Assam Secretariat Printing Office, Shillong, Assam), pp. 1-127.

Hay-Neave, D. (1953) Lai Chin Grammar and Exercises (Government Printing and Stationery, Yangon, Burma)

Himmelmann, N. (1996) "Demonstratives in Narrative Discourse A Taxonomy of Universal Uses," in Studies in Anaphora, edited by B. Fox (J. Benjamins Publishing, Philadelphia, Pennsylvania), pp. 205-254.

Hlun, C. (2007) "Pragmatic Influence on Pronouns in Lai (Hakha) Chin, with Especial Reference to Focus and Contrast," in SEALSXII: Papers from the 12th meeting of the Southeast Asian Linguistics Society (2002), edited by R. Wayland, J. Hartmann, \& P. Sidwell (Pacific Linguistics, Canberra, Australia), pp. 79-88.

Keenan, E. and Polinsky, M. (2001) "Malagasy (Austronesian)" in The Handbook of Morphology, edited by A. Spencer and A.M. Zwicky. (Blackwell, Oxford, England), pp. 563-623. 
Liu, H. \& Gu Y. (2009) "Free and not-so-free demonstratives in Jingpo" Journal of East Asian Linguistics 18 (2009), 273-295.

Peterson, D. (2002) "Hakha Lai” in The Sino-Tibetan Languages, edited by G. Thurgood and R. LaPolla (Routledge, New York, New York) pp. 409-426.

Reichle, V. (1981) "Bawm Language end Lore: Tibeto-Burman Area" Bulletin of the School of Oriental and African Studies 47 (03)

Rudin, C. (to appear) "Multiple Determination in Bulgarian and Macedonian DP," in Festschrift for Marc Greenberg in Slavica

Simons, G. and Fennig, C. (2018) Ethnologue: Languages of the World, Twenty-first edition (SIL International Dallas, Texas), Online version: http://www.ethnologue.com.

Tayeng, A. (1976) Milang Phrase-Book (Director of Information and Public Relations, Arunachal Pradesh)

VanBik, K. (2009) Proto-Kuki-Chin: A Reconstructed Ancestor of the Kuki-Chin Languages STEDT Monograph Series, Vol. 8. (University of California, Berkeley, California), pp. 1598.

Wilkins, D. (1999) "The 1999 demonstrative questionnaire: "This" and "that" in comparative perspective," in Manual for the 1999 Field Season, edited by D. Wilkins, (Max Planck Institute for Psycholinguistics, Nijmegen), pp. 1-24. 